\title{
Potential of Bacterial Endophytes as Plant Growth Promoting Factors
}

\section{Himani Chaturvedi, Vinod Singh* and Govind Gupta}

Department of Microbiology, Barkatullah University, Bhopal, Madhya Pradesh, India

\begin{abstract}
Endophytes colonize plants without causing any negative effects on them. They share a symbiotic relationship with their host and exert beneficial effects on them. They use various direct and indirect mechanisms to promote plant growth. A number of culture dependent and independent methods have been used to isolate and study endophytic bacteria. The endophyte communities isolated mainly belong to Proteobacteria, Firmicutes, Actinobacteria and Bacteroidetes. Bacteria utilize certain traits to colonize plants. In this colonization process various compounds released by both plants as well as bacteria play a major role. The plant growth promoting effects of bacterial endophytes have been seen in numerous important crops and it has been observed that they confer protection from various environmental stress factors as well.
\end{abstract}

Keywords: Endophytes; Plant colonization; Plant growth promotion mechanisms

\section{Introduction}

Endophytes may be defined as "Microbes that colonize living, internal tissues of plants without causing any immediate, overt negative effects" [1]. The symptomless nature of endophytic colonization in plant tissue aggravates the focus on their symbiotic and mutual relationship with plants but observation of diversity in the past years suggests that they can be pathogenic also. It has been observed that residing within plant tissues offer better communication opportunities than residing in the exospheric regions. Bacterial endophytes offer more benefits and are able to interact with the host in variable environmental conditions as well $[2,3]$. They enhance growth of plant by direct or indirect mechanisms. Direct promotion occurs either by increased acquisition of essential nutrients which involve nitrogen, phosphorus and iron or by modulation of hormone levels synthesizing auxin, cytokinin or gibberellins. In addition, some endophytes can lower levels of the phytohormone ethylene by synthesizing an enzyme, 1-aminocyclopropane-1-carboxylate (ACC) deaminase that cleaves the compound ACC, the immediate pre-cursor of ethylene in all higher plants. Indirect promotion occurs by inhibition by production of antagonistic substances against bacterial or fungal pathogens $[4,5]$.

\section{Diversity of Bacterial Endophytes}

Endophytic bacteria have been mainly studied using cultivation based methods but recent studies based on molecular methods reveal a completely different scenario. Endophytic species are much more diverse than what have been cultured in laboratories [6-9]. A study of wheat endophytes in Australia using molecular approach revealed a larger diversity of actinobacteria than that obtained by culturing endophytes [10]. Denaturing gradient gel electrophoresis profiles of 16S rRNA from citrus show bands, which do not match any isolated bacteria grown in culture media [11]. To analyze the presence of bacterial endophytes many techniques like taxon-specific real-time PCR, length-heterogeneity PCR, and genus-specific PCR have been used. A number of reviews have described the diversity of bacterial endophytes in multiple plant species, especially those with agronomical interest [12-14]. More recently, Romero et al. [15] demonstrated the power of the 16S-rRNA pyrosequencing approach in determining the composition of endophytic bacterial communities in tomato leafs (Solanum lycopersicum).

The endophyte communities isolated so far mainly comprised of Proteobacteria, including rhizobia in graminaceous plants, Firmicutes, Actinobacteria and Bacteroidetes [6]. Archaea do not appear to associate that tightly with plants. Although there are cultivationindependent studies [7-9] on few Archaea associated with roots, these Archaea occur on the surface of older roots [7] but have not been detected convincingly in internal plant tissues. Other phyla detected were Planctomycetes, Verrucomicrobia and Acidobacteria.

In a study conducted on tomato plants seven endophytic bacterial genetic groups were identified by polymerase chain reactionrestriction fragment length polymorphism (PCR-RFLP) and 16S rDNA sequence, and they were highly similar to Sphingomonas yanoikuya, Pseudomonas pseudoalcaligenes, Serratia marcescens, Bacillus megaterium, Paenibacillus polymyxa, B. pumilus and B. cereus. Four groups were identified in were highly similar to S. yanoikuyae, Pseudomonas fluorescens, Arthrobacter globiformis and Paenibacillus polymyxa [16]. Hopefully, this information will facilitate a more advanced understanding of how endophytes can be used in the field to improve crop production.

The most commonly found genera of bacterial endophytes are Pseudomonas, Bacillus, Burkholderia, Stenotrophomonas, Micrococcus, Pantoea, Microbacterium. [11-15,17-20].

\section{Colonization of Plants by Endophytes}

Endophytic bacteria have more advantage over rhizospheric bacteria because they get the opportunity to stay in direct contact with the plant tissues. Also, they offer more beneficial effects to the plants as compared to bacteria residing outside plants. However, rhizospheric colonials have been found to be the major source of endophytic colonization. Some people even consider endophytes as subsets of rhizospheric micro biome [11].

The rhizosphere offers an environment of high competition for microorganisms to occupy spaces and obtain nutrients [21]. Therefore, those organisms, either potentially beneficial or pathogenic and highly

*Corresponding author: Vinod Singh, Department of Microbiology, Barkatullah University, Bhopal, Madhya Pradesh, India, Tel: +919425712910; E-mail: vsingh3@rediffmail.com

Received September 08, 2016; Accepted September 20, 2016; Published September 22, 2016

Citation: Chaturvedi H, Singh V, Gupta G (2016) Potential of Bacterial Endophytes as Plant Growth Promoting Factors. J Plant Pathol Microbiol 7: 376. doi: $10.4172 / 2157-7471.1000376$

Copyright: (C) 2016 Chaturvedi $\mathrm{H}$, et al. This is an open-access article distributed under the terms of the Creative Commons Attribution License, which permits unrestricted use, distribution, and reproduction in any medium, provided the original author and source are credited. 


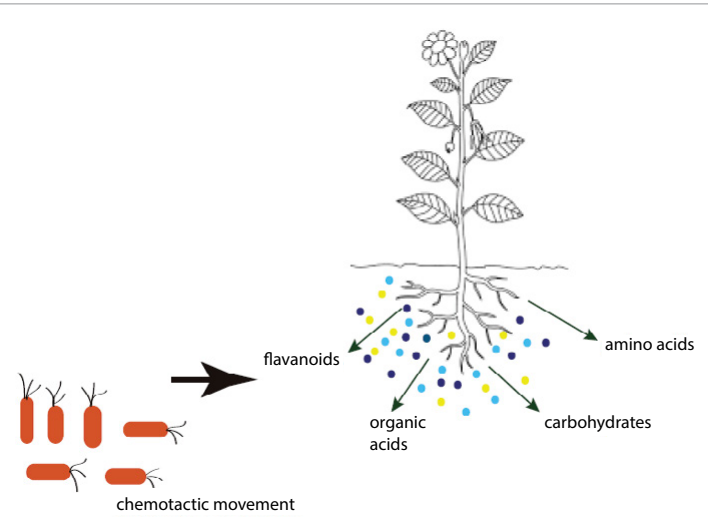

A

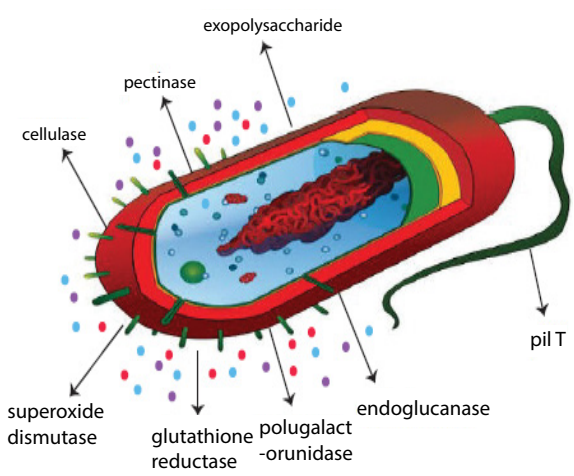

B

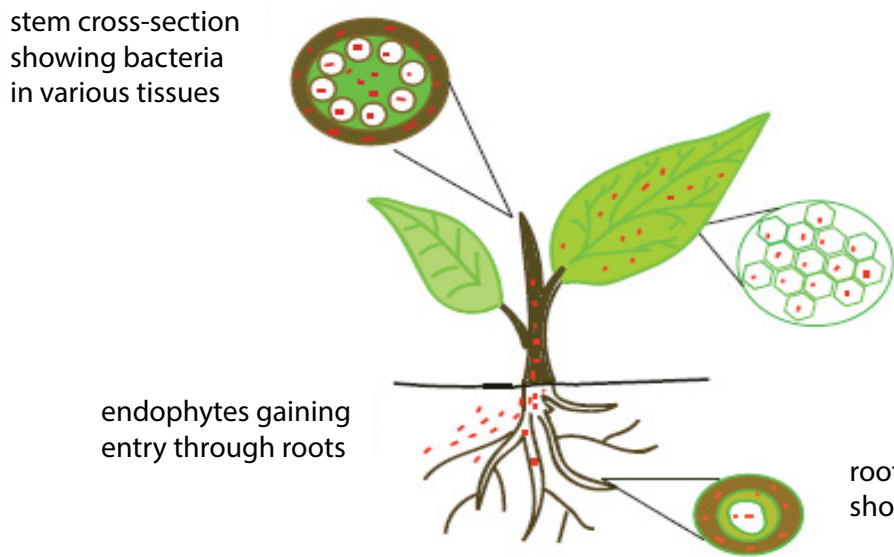

endophytes colonizing

leaf cells

C

Figure 1: A-Chemotactic movement of bacteria towards plant roots in response to exudates released by plant. B-Various molecules released by bacteria to colonize plants. C-Bacteria enter plants through roots and spread to other parts of the plant.

competitive in colonizing plant tissues and obtaining nutrients, will proliferate in this microenvironment and possibly have an effect on plant growth and development [22].

There are certain bacterial traits, which regulate the entire plantcolonization process collectively known as colonization traits. In the interactive colonization processes, communication between the plant and bacterium (and vice versa) has a key role [13]. It has been observed that bacterial root colonization often starts with the recognition of specific compounds in the root exudates by the bacteria [23]. These compounds probably also have major roles in below-ground community interactions [24]. Plants produce exudates from roots to interact with microorganisms for their own ecological and evolutionary benefit [25]. Flavonoids are considered as important compounds in plant-microbe communications [26]. They are possibly also important for competent endophytes to occupy a suitable and permanent niche in the rhizosphere and on roots.

Bacteria respond to these exudates by showing chemotactic movement towards them [27]. The response may differ in different endophytes. Root-exuded organic acids are major chemo-attractants in P. fluorescens-tomato interactions [23], whereas carbohydrates and amino acids attract Corynebacterium flavescens and Bacillus pumilus to rice [28]. The apparent specificity in these interactions probably relates to bacterial nutritional requirements and, in each of these cases, chemotaxis towards specific resources probably determines the specificity of the interaction (Figure 1).

Factors other than motility such as polysaccharide production in the rhizosphere have also been recognized as relevant traits that facilitate the colonization of plant roots in species like Alcaligenes faecalis and Azospirillum brasilense [29]. Mutational analyses suggest that surface characteristics of bacteria play an important role in the establishment of endophytes in roots. The lipopolysaccharide composition, particularly the rhamnose content had an impact on attachment to and endophytic colonization of maize roots by $H$. seropedicae [30]. In a study conducted on rice plant it was found that exopolysaccharide production is necessary for plant colonization by the nitrogen-Fixing endophyte Gluconacetobacter diazotrophicus [31]. This microbe also colonizes sugarcane and according to a study conducted by Letícia MS. According to Lery et al. a large array of protein signaling molecules are produced by it to colonize sugarcane [32]. In yet another study conducted by Sylvia Alquéres et al. it has been observed that the bacterial superoxide dismutase and glutathione reductase are crucial for endophytic colonization of rice Roots by 


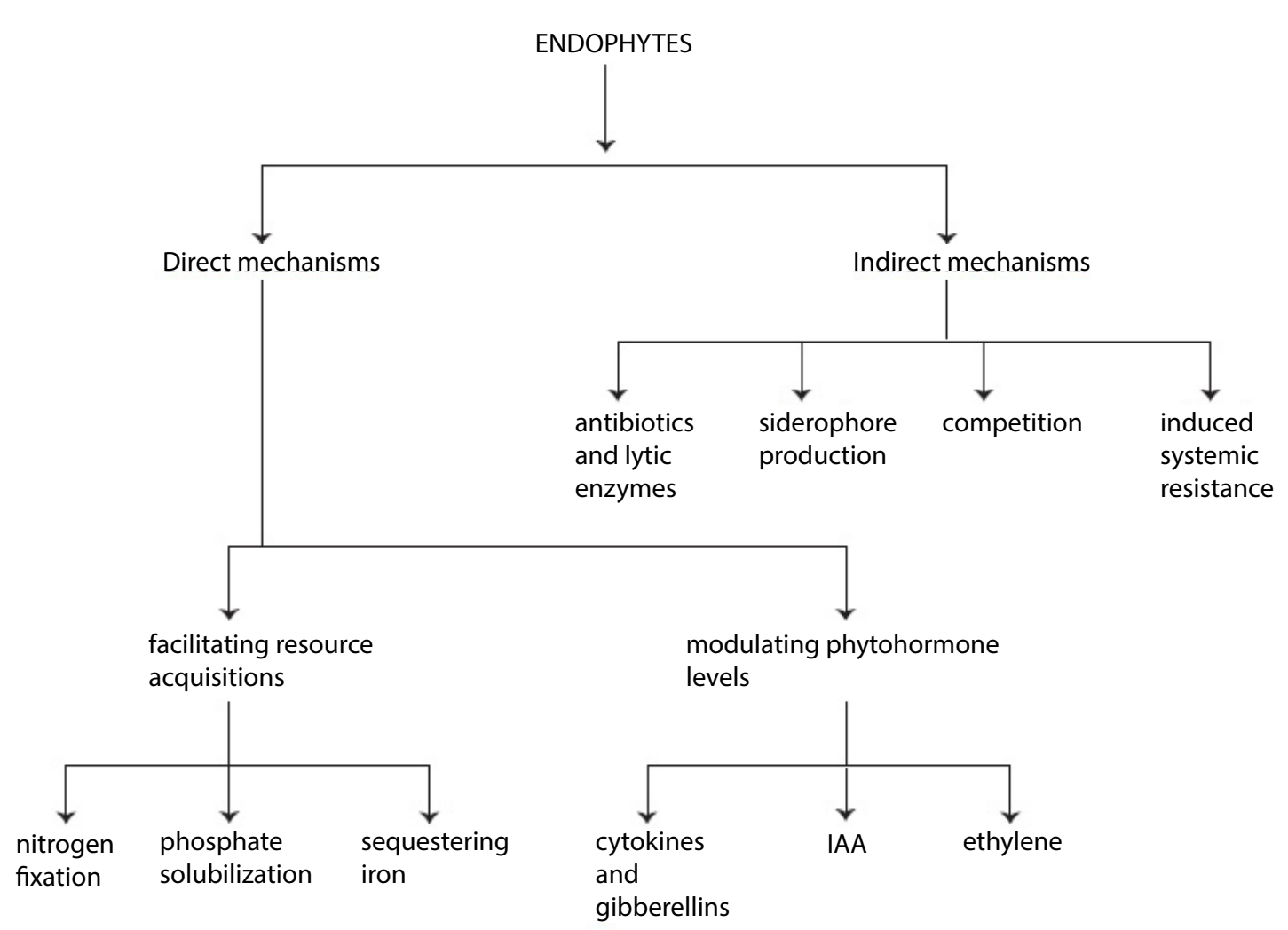

Figure 2: Outline of various mechanisms adapted by endophytes to promote plant growth.

Gluconacetobacter diazotrophicus PAL5 [33]. Type IV pili, which are important virulence factors in many pathogenic interactions of gramnegative bacteria, were in the grass endophyte Azoarcus sp. BH72 found to be essential for biofilm formation on the surface of rice roots [34] and subsequently also for endophytic spreading into shoots [35]. For endophytic colonization, not only attachment might be instrumental, but also motility: type IV pili are required for "twitching" motility on solid surfaces, which depends on PilT-mediated retraction of pili. This suggests that endophytic spreading of bacteria inside the host is an active process involving motility on plant surfaces, as has been shown for pathogenic Xylella spp., which use the type IV pili for twitching mediated, downward migration in the host vascular system [36]. Plantpolymer degrading enzymes such as cellulases and pectinases have also been suspected to play a role for internal colonization. Ingress into root epidermis cells was reduced, as well [35]. In grapevine, it has been shown that polygalacturonidase and endoglucanase of Xylella fastidosa enlarge the pore sizes of pit membranes, polysaccharide structures that separate adjacent xylem vessels and limit bacterial passage, and thereby presumably facilitating the systemic spread of these bacteria in the plant [37]. Thus, successful endophytes can be expected to be equipped with a set of cell wall degrading enzymes with confined, localized activity.

It has been suggested endophytes employ different mechanisms to gain entry into the plant tissues, particularly in roots. Except for already established seed-endophytes [38] the most common mode of entry of endophytic bacteria into plant tissues is through primary and lateral root cracks, and diverse tissue wounds occurring as a result of plant growth [39]. Because root wounds allow the leakage of plant metabolites, they become sites that attract bacteria [12]. Other sites through which endophytes enter plants include stomata, particularly on leaves and young stems, lenticels, which usually are present in the periderm of stems and roots [40]; and germinating radicles [41]. Bacteria can also enter via emergence of lateral roots or root hair cells, studies in cotton plants by Hallmann et al. [12] demonstrated that plant entry by the endophytic bacterium Enterobacter asburiae JM22 was assisted by ability of the bacterium to hydrolyze plant cell wall-bound cellulose. On the other hand, the bacterial species Herbaspirillum seropedicae, which lacks genes for degrading plant cell walls, is also a successful endophyte, confirming the existence of other strategies to penetrate plant tissues $[42,43]$. It not currently known whether there is any specific form of communication (other than chemotaxis) between endophytic bacteria and plants that is involved in the colonization of the internal tissues of plants, comparable to the mechanisms used by various Rhizobia spp. [44]. Rhizobia spp. is also an endophyte that colonizes the internal plant tissues and form nodules, where the nitrogen fixation process is carried out [45].

As soon as their cells are inside the plant, competent endophytes respond to plant cues to enable further induction of cellular processes necessary for entering the endophytic life stage and spreading to other (intercellular) tissues of the root cortex and beyond. Production of enzymes, such as endoglucanases [35] and endopolygalacturonidases [25], seems to be indispensable in this process. At this point, competent endophytes can quickly multiply inside the plant $[46,47]$, often reaching high cell numbers [48].

\section{Plant Growth Promotion Mechanisms}

Outlines of different mechanisms by which bacteria promote the growth of plants have been mentioned in the Figure 2. Both rhizospheric bacteria as well as endophytic bacteria have been shown to have plant growth promoting properties [49] and they utilize similar mechanisms as well. The endophytes have an advantage over 
rhizospheric colonizers, once they are established within the tissues of the host plant, are no longer subject to the variations of changing soil conditions. These changing conditions, which may inhibit the functioning and proliferation of rhizospheric bacteria, include variations in temperature, soil $\mathrm{pH}$ and water content, and the presence of soil bacteria that may compete for binding sites on host plant root surfaces [50].

The growth stimulation by the microorganisms can be a consequence of nitrogen fixation [51,52] or the production of phytohormones, biocontrol of phytopathogens in the root zone (through production of antifungal or antibacterial agents, siderophore production, nutrient competition and induction of systematic acquired host resistance, or immunity) or by enhancing availability of minerals [53,54].

The understanding of the various mechanisms that promote plant growth can be helpful in selecting species and conditions for maximum benefits. Ryu et al. studied that some bacteria produced volatile substances such as 2-3 butanediol and aceotin to benefit plants [55]. Endophytes produce adenine ribosides that stimulate growth and mitigate browning of pine tissues [56].

In this review we have summarized some recent researches in which endophytes have been found to play a major role.

\section{Rice}

A nitrogen-fixing endophyte Azocarus sp. has been found to infect plants through the emergence points of lateral roots and root tips via the action of a bacterial endoglucanase [35]. It has been confirmed because mutants lacking the activity of this endoglucanase colonized rice plants to a significantly lesser extent. Also it was seen that that deletion mutants of the pilT and pilA genes in this bacterium abolished bacterial witching and motility as well as the endophytic colonization of the roots of rice plants [57], where PilT and PilA encode the pilus retraction protein and the pilin structural protein, respectively.

\section{Potato}

Two different potato cultivars were found to respond differently to the bacterial treatment. To better under-stand the significance of these results, this study needs to be expanded using different bacterial strains and their mutants. For example, in one study researchers elaborated a series of DNA cytosine methylation changes that occurred as a consequence of plant inoculation with the endophytic PGPB $B$. phytofirmans PsJN [58]. In this study, 30 plant proteins (thought to be involved in growth and signaling) whose methylation status was significantly altered (increased or decreased) were identified following interaction with the bacterium.

\section{Sugarcane}

Proteomics helps to better understand the detailed changes effected by an endophytic PGPB (plant growth promoting bacteria) like the impact of an endophytic PGPB on plant protein expression. Thus, when the effect of the endophytic PGPB Glucanoacetobacter diazotrophicus on sugar-cane plants was assessed, of the more than 400 proteins that were analyzed, 78 were differentially expressed in the presence of the bacterium [32]. As observed with potatoes and cytosine methylation, two different cultivars of sugarcane responded differently to the bacterial treatment.

\section{Tomato}

In a recent research conducted by Romero et al. potentially endophytic culturable bacteria from leaves of cultivated tomato were isolated and analyzed for their potential for growth promotion and biocontrol of diseases caused by Botrytis cinerea and Pseudomonas syringae. Bacterial species closely related to Exiguobacterium spp were found to show antagonistic properties against them.

It has been investigated that the endophytic bacterial communities in tomato varieties having differing resistance (or susceptibility) to Ralstonia solanacearum. Seven endophytic bacterial genetic groups were identified by polymerase chain reaction- restriction fragment length polymorphism [PCR-RFLP] and 16S rDNA sequence, and they were highly similar to Sphingomonas yanoikuya, Pseudomonas pseudoalcaligenes, Serratia marcescens, Bacillus megaterium, Paenibacillus polymyxa, B. pumilus, B. cereus. S. yanoikuyae, Pseudomonas fluorescens, Arthrobacter globiformis and Paenibacillus polymyxa. In addition, antagonistic endophytes were identified by $16 \mathrm{~S}$ rRNA gene analysis, and tested for their abilities to protect tomato plants from infection with $R$. solanacearum [16].

Utilizing bacterial endophytes that can colonize a wide range of different plant tissues, one group reported applying a particular endophytic bacterium to plant flowers (e.g. by spraying) so that it might be present within the seeds [59].

Therefore, it appears that the response of a plant to an endophytic bacterium is not simple or universal but rather is dependent upon both plant and bacterial determinants.

\section{Modulating the Effects of Environmental Stress}

Under ideal circumstances, a large portion of a plants growth and

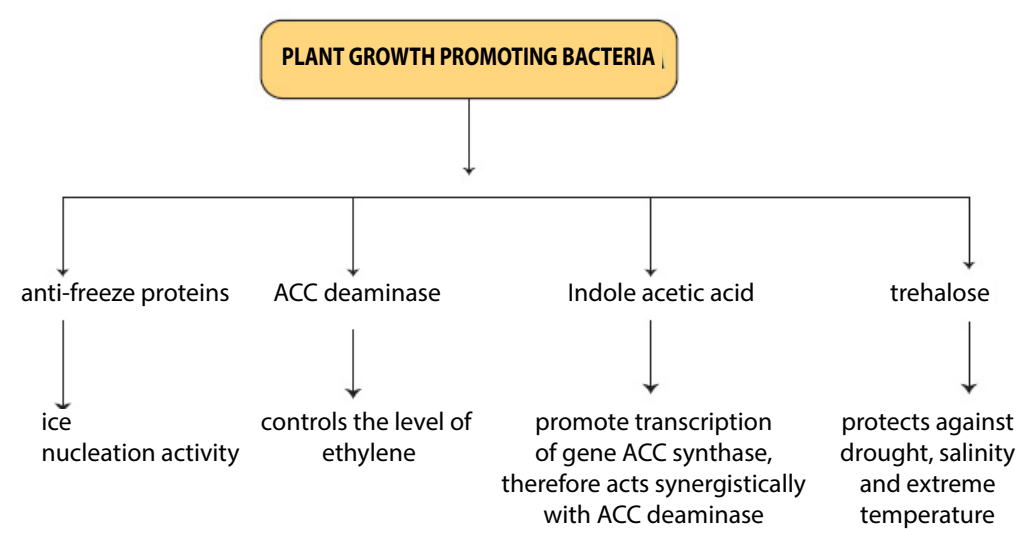

Figure 3: Ways in which bacteria protects the plants from environmental stress [61-65]. 
development may be thought of as proceeding in a more or less linear fashion over time [60]. However, in the field, the growth of plants may be inhibited by a large number of different biotic and abiotic stresses. These stresses include extremes of temperature, high light, flooding, drought, the presence of toxic metals and environmental organic contaminants, radiation, wounding, insect predation, nematodes, high salt, and various pathogens including viruses, bacteria and fungi. Therefore, as a consequence of these many different environmental stresses, plant growth is invariably lower than it would be in their absence. When they are added to plants, PGPB may employ any one or more of several different mechanistic strategies in an effort to overcome this growth inhibition. The following Figure 3 summarizes the various biotic and abiotic stress and the mechanisms adapted by endophytes to confer protection to plants [61-65].

\section{Conclusion}

Endophytes seem to play an important role in promoting growth of plants and protecting them against biotic and abiotic factors. These bacteria are being used successfully in a number of countries in the developing world. This can be used to reduce the amount of chemicals utilized in agriculture, which is becoming a leading cause of pollution these days. The enhancement of bacterial colonization spurred by specific carbonaceous exudates by plant roots and the capacity of certain bacteria to modulate plant metabolism are key issues for further study, because these could provide insight into possibly mutualistic plant-endophyte relationships.

\section{Acknowledgement}

We are grateful to Department of Microbiology, Barkatullah University, India that allowed us to carry out this work.

\section{References}

1. Bacon CW, White JF (2000) Microbial endophytes. Marcel Dekker Inc., New York, N.Y.

2. Ali S, Charles TC, Glick BR (2012) Delay of flower senescence by bacterial endophytes expressing 1-aminocyclopropane-1-carboxylate deaminase. J Appl Microbiol 113: 1139-1144.

3. Coutinho BG, Licastro D, Mendonça-Previato L, Cámara M, Venturi V (2015) Plant-influenced gene expression in the rice endophyte Burkholderia kururiensis M130. Mol Plant Microbe Interact 28: 10-21.

4. Glick BR (2015) Beneficial plant-bacterial interactions. Springer, Heidelberg.

5. Saini R, Dudeja SS, Giri R, Kumar V (2015) Isolation, characterization, and evaluation of bacterial root and nodule endophytes from chickpea cultivated in Northern India. J Basic Microbiol 55: 74-81.

6. Rosenblueth MH, Martínez-Romero E (2006) Bacterial endophytes and their interactions with hosts. Mol Plant Microbe Interact 19: 827-837.

7. Chelius MK, Triplett EW (2001) The diversity of archaea and bacteria in association with the roots of Zea mays L. Microb Ecol 41: 252-263.

8. Sun L, Qiu F, Zhang X, Dai X, Dong X, et al. (2008) Endophytic bacterial diversity in rice (Oryza sativa L.) roots estimated by 16S rDNA sequence analysis. Microb Ecol 55: 415-424.

9. Grokopf R, Stubner S, Liesack W (1998) Novel euryarchaeotal lineages detected on rice roots and in the anoxic bulk soil of flooded rice microcosms. Appl Environ Microbiol 64: 4983-4989.

10. Conn VM, Franco CMM (2004) Analysis of the endophytic actinobacterial population in the roots of wheat (Triticum aestivum L.) by terminal restriction fragment length polymorphism and sequencing of $16 \mathrm{~S}$ rRNA clones. Appl Environ Microbiol 70: 1787-1794.

11. Araujo WL, Marcon J, Maccheroni W, Van Elsas JD Jr, Van Vuurde JWL, et al (2002) Diversity of endophytic bacterial populations and their interaction with Xylella fastidiosa in citrus plants. Appl Environ Microbiol 68: 4906-4914.

12. Hallmann J, Quadt-Hallmann A, Mahaffee WF, Kloepper JW (1997) Bacterial endophytes in agricultural crops. Can J Microbiol 43: 895-914.
13. Rosenblueth M, Martínez-Romero E (2006) Bacterial endophytes and their interactions with hosts. Mol Plant Microbe Interact 19: 827-837.

14. Sturz AV, Nowak J (2000) Endophytic communities of rhizobacteria and the strategies required to create yield enhancing associations with crops. Appl Soil Ecol 15: 183-190.

15. Romero FM, Marina M, Pieckenstain FL (2014) The communities of tomato (Solanum lycopersicum L.) leaf endophytic bacteria, analyzed by $16 \mathrm{~S}$-ribosomal RNA gene pyrosequencing. FEMS Microbiol Lett 351: 187-194.

16. Hang F, Yanchang L, Qiongguang L (2013) Endophytic bacterial communities in tomato plants with differential resistance to Ralstonia solanacearum. African Journal of Microbiological Research 7: 1311-1318.

17. Shi Y, Yang H, Zhang T, Sun J, Lou K (2014) Illumina-based analysis of endophytic bacterial diversity and space-time dynamics in sugar beet on the north slope of Tianshan mountain. Appl Microbiol Biotechnol 98: 6375-6385.

18. Sun Y, Cheng Z, Glick BR (2009) The presence of a 1-aminocyclopropane-1carboxylate $(A C C)$ deaminase deletion mutation alters the physiology of the endophytic plant growth-promoting bacterium Burkholderia phytofirmans PsJN. FEMS Microbiol Lett 296: 131-136.

19. Santoyo G, Moreno-Hagelsieb G, Orozco-Mosqueda Mdel C, Glick BR (2016) Plant growth-promoting bacterial endophytes. Microbiol Res 183: 92-99.

20. Marquez-Santacruz HA Hernandez-Leon R, Orozco-Mosqueda MC Velazquez-Sepulveda, I, Santoyo G (2010) Diversity of bacterial endophytes in roots of Mexican husk tomato plants (Physalis ixocarpa) and their detection in the rhizosphere. Gen Mol Res 9: 2372-2380.

21. Raaijmakers JM, Vlami M, De Souza JT (2002) Antibiotic production by bacterial biocontrol agents. Antonie Van Leeuwenhoek 81: 537-547.

22. Haas D, Keel C (2003) Regulation of antibiotic production in root-colonizing Peudomonas spp. and relevance for biological control of plant disease. Annu Rev Phytopathol 41: 117-153.

23. De Weert S, Vermeiren H, Mulders IH, Kuiper I, Hendrickx N, et al. (2002) Flagella-driven chemotaxis towards exudate components is an important trait for tomato root colonization by Pseudomonas fluorescens. Mol Plant Microbe Interact 15: 1173-1180.

24. Bais HP, Park SW, Weir TL, Callaway RM, Vivanco JM (2004) How plants communicate using the underground information superhighway. Trends Plant Sci 9: 26-32.

25. Compant S, Duffy B, Nowak J, Clément C, Barka EA (2005) Use of plant growthpromoting bacteria for biocontrol of plant diseases: principles, mechanisms of action, and future prospects. Appl Environ Microbiol 71: 4951-4959.

26. Shaw LJ, Morris P, Hooker JE (2006) Perception and modification of plan flavonoid signals by rhizosphere microorganisms. Environ Microbiol 8: 1867-1880.

27. Lugtenberg BJ, Dekkers L, Bloemberg GV (2001) Molecular determinants of rhizosphere colonization by Pseudomonas. Annu Rev Phytopathol 39 461-490.

28. Bacilio-Jimenez M (2003) Chemical characterization of root exudates from rice (Oryza sativa) and their effects on the chemotactic response of endophytic bacteria. Plant Soil 249: 271-277.

29. You CB, Lin M, Fang XJ, Song W (1995) Attachment of Alcaligenes to rice roots. Soil Biol Biochem 27: 463-466.

30. Balsanelli E, Serrato RV, De Baura VA, Sassaki G, Yates MG, et al. (2010) Herbaspirillum seropedicae $\mathrm{rbB}$ and $\mathrm{rfb}$ genes are required for maize colonization. Environ Microbiol 12: 2233-2244.

31. Carlos HSG, Luc FM, Jean L, Marcia S, José I (2011) Exopolysaccharide production is required for biofilm formation and plant colonization by the nitrogen-fixing endophyte Gluconacetobacter diazotrophicus. MPMI 24: 1448 1458

32. Letícia MS, Adriana S, Eduardo M, Wanda MA, Paulo M (2011) Quantitative proteomic analysis of the interaction between the endophytic plant-growthpromoting bacterium Gluconacetobacter diazotrophicus and Sugarcane. MPMI 24: $562-576$.

33. Sylvia A, Carlos M, Luc R, Michael R, Ivo B, et al. (2013) The bacterial superoxide dismutase and glutathione reductase are crucial for endophytic colonization of rice roots by Gluconacetobacter diazotrophicus PAL5. MPM 26: 937-945 
Citation: Chaturvedi H, Singh V, Gupta G (2016) Potential of Bacterial Endophytes as Plant Growth Promoting Factors. J Plant Pathol Microbiol 7: 376. doi: $10.4172 / 2157-7471.1000376$

34. Dörr J, Hurek T, Reinhold-Hurek B (1998) Type IV pili are involved in plantmicrobe and fungus-microbe interactions. Mol Microbiol 30: 7-17.

35. Reinhold-Hurek B, Maes T, Gemmer S, Van Montagu M, Hurek T (2006) An endoglucanase is involved in infection of rice roots by the not-cellulosemetabolizing endophyte Azoarcus sp. strain $\mathrm{BH} 72$. Mol Plant Microbe Interact 19: $181-188$.

36. Meng Y, Li Y, Galvani CD, Hao G, Turner JN, et al. (2005) Upstream migration of Xylella fastidiosa via pilus-driven twitching motility. J Bacteriol 187: 5560-

37. Pérez-Donoso AG, Sun Q, Roper MC, Greve LC, Kirkpatrick B, et al. (2010) Cell wall-degrading enzymes enlarge the pore size of intervessel pit membranes in healthy and Xylella fastidiosa-infected grapevines. Plant Physiol 152: 1748-

38. Truyens S, Weyens N, Cuypers A, Vangronsveld J (2014) Bacterial seed endophytes: genera, vertical transmission and interaction with plants. Environ Microbiol Rep 7: 40-50

39. Sessitsch A, Coenye T, Sturz AV, Vandamme P, Barka EA, et al. (2005) Burkholderia phytofirmans sp. nov., a novel plant-associated bacterium with plant-beneficial properties. Int J Syst Evol Microbiol 55: 1187-1192.

40. Scott RI, Chard JM, Hocart MJ, Lennard JH, Graham DC (1996) Penetration of potato tuber lenticels by bacteria in relation to biological control of black leg disease. Potato Res 39: 333-344.

41. Gagné S, Richard C, Rouseau H, Antoun H (1987) Xylem-residing bacteria in alfalfa roots. Can J Microbiol 33: 996-1000.

42. Pedrosa FO, Monteiro RA, Wassem R, Cruz LM, Ayub RA, et al. (2011) Genome of Herbaspirillum seropedicae strain SmR1, a specialized diazotrophic endophyte of tropical grasses. PLoS Genet 7: e1002064.

43. Wisniewski-Dyé F, Borziak K, Khalsa-Moyers G, Alexandre G, Sukharnikov LO, et al. (2011) Azospirillum genomes reveal transition of bacteria from aquatic to terrestrial environments. PLoS Genet 7: e1002430.

44. Spaink HP (2000) Root nodulation and infection factors produced by rhizobia bacteria. Annu Rev Microbiol 54: 257-288.

45. Compant S, Reiter B, Sessitsch A, Nowak J, Clément C, et al. (2005) Endophytic colonization of Vitis vinifera $\mathrm{L}$. by plant growth-promoting bacterium Burkholderia sp. strain PsJN. Appl Environ Microbiol 71: 1685-1693.

46. Dong YM (2003) Kinetics and strain specificity of rhizosphere and endophytic colonization by enteric bacteria on seedlings of Medicago sativa and Medicago truncatula. Appl Environ Microbiol 69: 1783-1790.

47. Zakria M (2007) Colonization and nitrogen-fixing ability of Herbaspirillum sp strain B501 gfp1 and assessment of its growth promoting ability in cultivated rice. Microbes Environ 22: 197-206.

48. Barraquio WL (1997) Isolation of endophytic diazotrophic bacteria from wetland rice. Plant Soil 194: 15-24.

49. Lacava PT, Azevedo JL (2013) Endophytic bacteria: a biotechnologica potential in agrobiology system. In: Maheshwari, DK Saraf, Aeron AM (eds.), Bacteria in agrobiology: Crop productivity. Springer-Verlag, Berlin, Heidelberg pp: $1-44$
50. Glick BR (2012) Plant growth-promoting bacteria: mechanisms and applications. Scientifica (Cairo) 2012: 963401.

51. Hurek T, Handley LL, Reinhold-Hurek B, Piché Y (2002) Azoarcus grass endophytes contribute fixed nitrogen to the plant in an unculturable state. Mo Plant Microbe Interact 15: 233-242.

52. Iniguez AL, Dong Y, Triplett EW (2004) Nitrogen fixation in wheat provided by Klebsiella pneumoniae 342. Mol Plant Microbe Interact 17: 1078-1085.

53. Sessitsch A, Howieson JG, Perret X, Antoun H, Martínez- Romero E (2002) Advances in Rhizobium research. Crit Rev Plant Sci 21: 323-378.

54. Sturz AV, Christie BR, Nowak J (2000) Bacterial endophytes: Potential role in developing sustainable systems of crop production. Crit Rev Plant Sci 19: 1-30

55. Ryu CM, Farag MA, Hu CH, Reddy MS, Wei HX, et al. (2003) Bacterial volatiles promote growth in Arabidopsis. Proc Natl Acad Sci USA 100: 4927-4932.

56. Pirttilä AM, Joensuu P, Pospiech H, Jalonen J, Hohtola A (2004) Bud endophytes of Scots pine produce adenine derivatives and other compounds that affect morphology and mitigate browning of callus cultures. Physiol Plantarum 121: 305-312.

57. Böhm M, Hurek T, Reinhold-Hurek B (2007) Twitching motility is essential for endophytic rice colonization by the N2-fixing endophyte Azoarcus sp. strain BH72. Mol Plant Microbe Interact 20: 526-533.

58. Da K, Nowak J, Flinn B (2012) Potato cytosine methylation and gene expression changes induced by a beneficial bacterial endophyte, Burkholderia phytofirmans strain PsJN. Plant Physiol Biochem 50: 24-34

59. Mitter B, Sessitsch A, Naveed M (2013) Method for producing plant seed containing endophytic micro-organisms. European paten.

60. Glick BR, Cheng Z, Czarny J, Duan J (2007) Promotion of plant growth by ACC deaminase-producing soil bacteria. Eur J Plant Pathol 119: 329-339.

61. Gamalero E, Glick BR (2010) Bacterial ACC deaminase and IAA: interactions and consequences for plant growth in polluted environments, in Handbook of Phytoremediation, IA. Golubev, (ed), Nova Science, New York, NY, USA. pp. 763-774.

62. De-Bashan LE, Hernandez JP, Nelson KN, Bashan Y, Maier RM (2010) Growth of quail bush in acidic, metalliferous desert mine tailings: effect of Azospirillum brasilense $\mathrm{Sp} 6$ on biomass production and Rhizosphere community structure. Microbial Ecology 60: 915-927.

63. Siddikee MA, Chauhan PS, Anandham R, Han GH, Sa T (2010) Isolation, characterization, and use for plant growth promotion under salt stress, of ACC deaminase-producing halotolerant bacteria derived from coastal soil. $J$ Microbiol Biotechnol 20: 1577-1584.

4. Sgroy V, Cassán F, Masciarelli O, Del Papa MF, Lagares A, et al. (2009) Isolation and characterization of endophytic plant growth-promoting (PGPB) or stress homeostasis-regulating (PSHB) bacteria associated to the halophyte Prosopis strombulifera. Appl Microbiol Biotechnol 85: 371-381.

65. Xu H, Griffith M, Patten CL, Glick BR (1998) Isolation and characterization of an antifreeze protein with ice nucleation activity from the plant growth promoting rhizobacterium Pseudomonas putida GR12-2. Canadian Journal of Microbiology 44: 64-73. 